\title{
The Relationship between Blood Glycosylated Haemoglobin and Home Capillary Blood Glucose Levels in Diabetics
}

\author{
R. B. Paisey ${ }^{1}$, D. G. Macfarlane ${ }^{1}$, R. J. Sherriff ${ }^{1}$, M. Hartog $^{1}$, R. R. Slade $^{2}$, and D. A. J. White ${ }^{2}$ \\ ${ }^{1}$ University Department of Medicine, Bristol Royal Infirmary, and ${ }^{2}$ Department of Haematology, Southmead Hospital, Bristol, England
}

Summary. Serial capillary blood glucose levels from insulin treated patients were recorded over 24 hour periods at fortnightly intervals for three months. Total glycosylated haemoglobin as $\%$ of $\mathrm{HbA}$ was measured at the end of this period by the Flückiger method, and $\% \mathrm{HbA}_{1}$ by column chromatography. There were highly significant correlations between mean blood glucose levels over the three months and $\% \mathrm{HbA}_{1} \quad(\mathrm{r}=0.93,95 \%$ confidence limits 0.84-0.98), and with total glycosylated haemoglobin $(r=0.88,95 \%$ confidence limits $0.75-0.94)$. There was also a good correlation between results obtained by the two methods $(\mathrm{r}=0.81, \mathrm{p}<0.0001)$. There were less strong correlations between $\% \mathrm{HbA}_{1}$ and blood glucose levels during each of the three months before the estimation, with percentage of glucose levels greater than $10 \mathrm{mmol} / 1$ and with mean fasting blood glucose. These data support the hypothesis that $\% \mathrm{HbA}_{1}$ and total glycosylated haemoglobin are satisfactory measurements of short term diabetic control.

Key words: Glycosylated haemoglobin, home blood glucose monitoring, diabetic control.

In order to assess the relationship between hyperglycaemia and diabetic complications, methods of measuring glycaemic control over long periods are highly desirable. Home monitoring of blood glucose with reflectance meters has recently become practicable $[1,2]$. We have developed an alternative filter paper method of capillary blood spot collection because it is cheaper and allows accurate laboratory blood glucose assay [3]. Furthermore, measurement of the percentage of glycosylated adult haemoglobin $\left(\% \mathrm{HbA}_{1}\right),[4-8]$, appears to provide an integrated measure of blood glucose levels for a period of several weeks [9-12]. The present study was carried out to discover how closely glycosylated haemoglobin $(\mathrm{Hb})$, as measured by two different techniques, correlated with home capillary blood glucose levels taken regularly over the preceding three months.

\section{Patients and Methods}

\section{Patients}

A group of cooperative and apparently fairly stable insulin dependent diabetics (Table 1) collected serial capillary blood samples by finger prick on to filter paper strips. Most were treated with twice daily, mixed long and short acting insulins (total doses from 16-124 units daily); five "sulphonylurea failures" received Monotard 20-36 units each morning. Three patients had proteinuria but none had a raised serum creatinine level at the time of the study. They took samples seven to eight times during a $24 \mathrm{~h}$ period: i. e. before and $2 \mathrm{~h}$ after breakfast, lunch and supper, on going to bed, and sometimes between 0200 and $0400 \mathrm{~h}$. The collection of the blood spots was demonstrated and patients were asked to take samples during a normal working day; informed consent was obtained from all. Patients who found the procedure acceptable and were able to produce adequate blood spots, were asked to take further $24 \mathrm{~h}$ series of capillary blood spots once every two weeks for three months. After this, blood was taken for measurement of

Table 1. Characteristics of the patients studied

\begin{tabular}{lclll}
\hline $\begin{array}{l}\text { Reason for insulin } \\
\text { treatment }\end{array}$ & Number & $\begin{array}{l}\text { Age } \\
\text { years }\end{array}$ & $\begin{array}{l}\text { Age at } \\
\text { diagnosis } \\
\text { years }\end{array}$ & $\begin{array}{l}\% \text { ideal } \\
\text { body } \\
\text { weight }\end{array}$ \\
\hline $\begin{array}{l}\text { Failed sulphonylurea } \\
\text { treatment }\end{array}$ & 10 & $36-70$ & $40-60$ & $90-110$ \\
$\begin{array}{l}\text { Ketosis prone dia- } \\
\text { betes from diagnosis }\end{array}$ & 29 & $19-50$ & $2-35$ & $90-120$ \\
$\begin{array}{l}\text { Pregnant: ketosis } \\
\text { prone diabetes }\end{array}$ & 1 & 25 & 12 & 104 \\
\hline
\end{tabular}




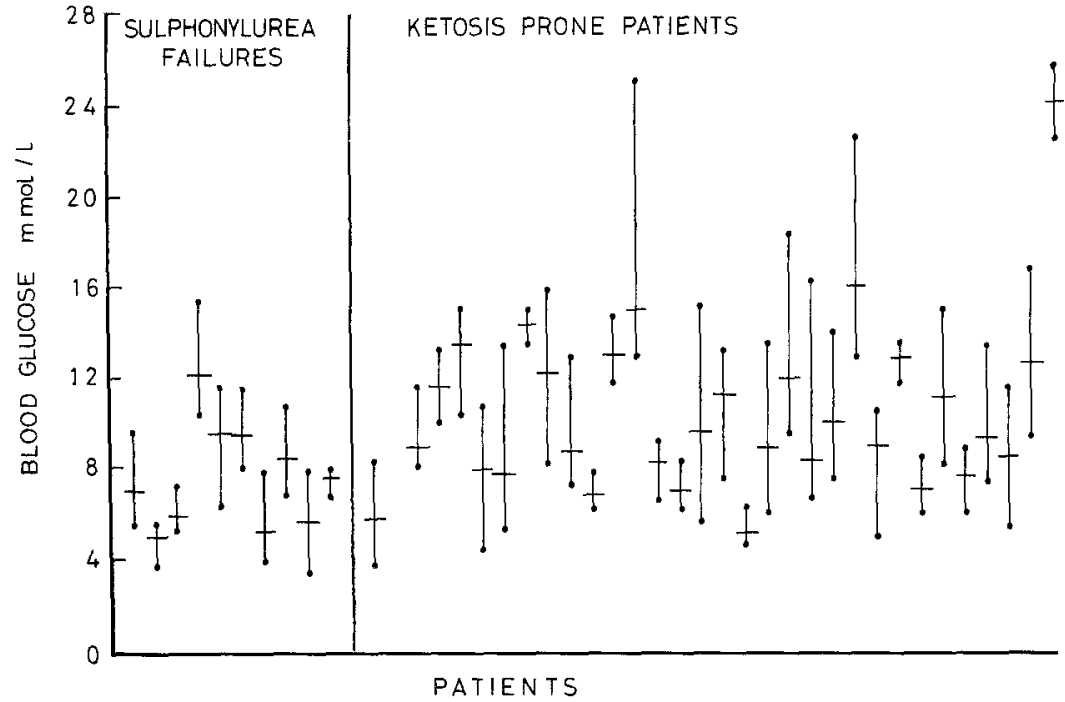

Fig. 1. Highest and lowest mean daily blood glucose levels during the study; the horizontal bar indicates mean of all blood glucose levels during the study

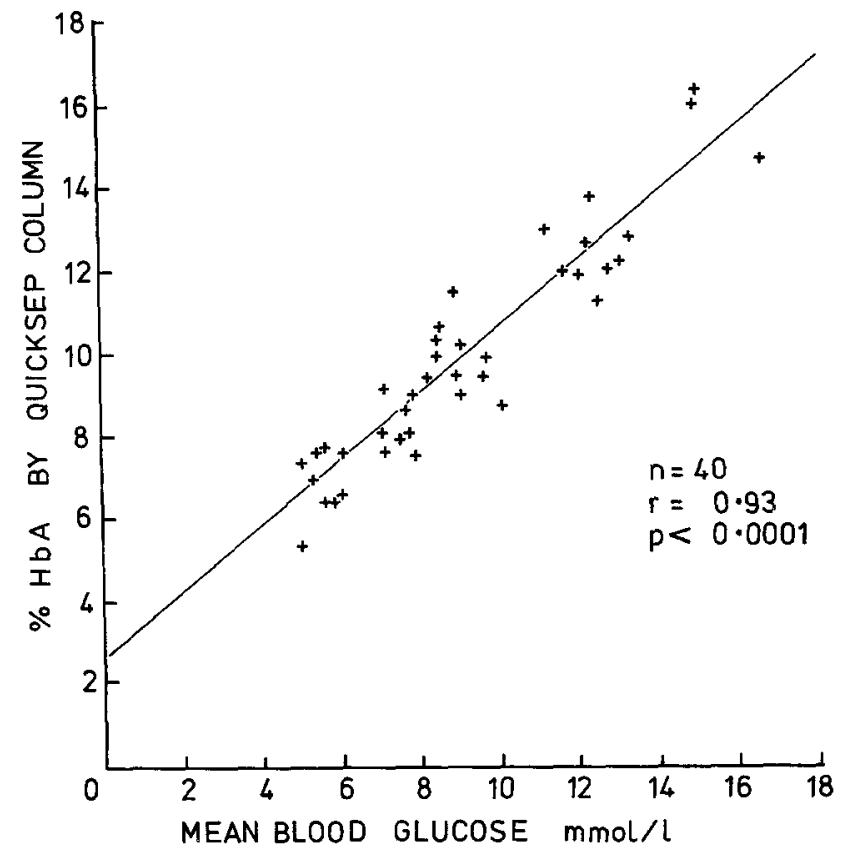

Fig. 2. The relationship between $\% \mathrm{HbA}_{1}$ measured by column chromatography and mean home blood glucose levels in the previous three months

glycosylated $\mathrm{Hb}$. Forty patients produced satisfactory blood spots, and all had estimations of \% $\mathrm{HbA}_{1}$ by the "Quik-Sep" column method (Isolab Incorporated, Drawer 4350, Arkron, Ohio, 44321 USA). Twenty seven also had measurements of total glycosylated $\mathrm{Hb}$ by the Flückiger method.

\section{Laboratory Methods}

Capillary blood glucose was measured in the filter paper spots by a modification [14] of the method previously described [3]. Filter paper previously soaked in $5 \%(\mathrm{w} / \mathrm{v})$ boric acid was used. A $6 \mathrm{~mm}$ diameter disc was punched from the centre of blood spots of adequate size and glucose eluted for one hour in $300 \mu \mathrm{l}$ of $21 / 2 \%(\mathrm{v} / \mathrm{v})$ sulphosalicylic acid. Glucose concentration in the eluate was measured on the glucose oxidase autoanalyser, bypassing the dialysis stage to increase sensitivity. Blood glucose was calculated on the basis that each disc of filter paper absorbed $11.0 \pm 0.4 \mu \mathrm{l} \mathrm{blood}$ (mean $\pm 2 \mathrm{SD}$ ).

Glycosylated $\mathrm{Hb}$ was measured by a colorimetric method [5], and $\% \mathrm{HbA}_{1}$ by "Quik-Sep" column chromatography. The latter is a commercial kit application of small column techniques to separate faster moving glycosylated haemoglobins $\left(\mathrm{HbA}_{1+a+b+c}\right)$ from unaltered $\mathrm{HbA}[4,6]$. Our coefficient of variation for the Flückiger method is $5.5 \%$ and for the column method $3 \%$. The range of normal values, for the colorimetric and column assays are $5.3 \pm$ $1.6 \%$ and $7.2 \pm 1.2 \%$ respectively (mean $\pm 2 \mathrm{SD}$ ).

Results were analysed by least squares linear regression to obtain correlation coefficients.

\section{Results}

Although the patients were selected for being cooperative and apparently well controlled, some showed considerable hyperglycaemia during the period of study (Fig. 1), and had considerable diurnal fluctuation of blood glucose.

There were highly significant correlations between the measurements of glycosylated $\mathrm{Hb}$ by both methods, and the mean of the blood glucose levels during the previous three months (Fig. 2), although the correlation was somewhat less close for the Flückiger estimation $(\mathrm{r}=0.88, \mathrm{p}<0.0001)$. Measurement of glycosylated $\mathrm{Hb}$ on the same blood sample by the two methods showed good agreement $(\mathrm{r}=0.88, \mathrm{p}<0.0001)$.

The figures were further analysed to assess the degree of correlation of $\% \mathrm{HbA}_{1}$ with mean blood glucose levels during the first, second and third 
Table 2. Correlation coefficients of $\% \mathrm{HbA}_{1}$ with home capillary blood glucose levels in the preceding three months

\begin{tabular}{|c|c|c|c|c|c|c|}
\hline & \multicolumn{6}{|c|}{ Capillary blood glucose } \\
\hline & $\begin{array}{l}\text { Mean of } \\
\text { 3rd month } \\
\text { before }\end{array}$ & $\begin{array}{l}\text { Mean of } \\
\text { 2nd month } \\
\text { before }\end{array}$ & $\begin{array}{l}\text { Mean of } \\
\text { one month } \\
\text { before }\end{array}$ & Mean fasting ${ }^{\mathrm{a}}$ & $\begin{array}{l}\% \text { above or } \\
\text { below } \\
10 \mathrm{mmol} / 1^{\mathrm{a}}\end{array}$ & $\begin{array}{l}\text { Maximum } \\
\text { diurnal } \\
\text { fluctuation }\end{array}$ \\
\hline $\begin{array}{l}\text { "Quick-Sep" } \\
\text { column \% HbA } 1\end{array}$ & $0.89^{d}$ & $0.86^{d}$ & $0.88^{d}$ & $0.69^{b}$ & $0.85^{\mathrm{d}}$ & $0.49^{\mathrm{b}}$ \\
\hline
\end{tabular}

months before the estimation, the \% of blood glucose levels $>10 \mathrm{mmol} / \mathrm{l}$, the mean fasting blood glucose, and with the maximum fluctuations of blood glucose over 24 hours. The results (Table 2) showed that these indices of diabetic control did correlate with \% $\mathrm{HbA}_{1}$, though none of the associations was as strong as that between the mean blood glucose during the whole of the previous three months and $\% \mathrm{HbA}_{1}$.

\section{Discussion}

Collection of blood samples on to filter paper strips is a satisfactory method for measuring blood glucose levels taken by patients at home. There were very close correlations between the mean $24 \mathrm{~h}$ blood glucose taken fortnightly during the previous three months and the levels of glycosylated haemoglobin particularly as measured by column chromatography. Others have also shown good correlations between blood glucose levels measured in out-patient clinics or in the ward, and the level of glycosylated haemoglobin [4-12]. On the whole, however, these correlations have been less close than those found in the present study. This supports the expectation that home blood glucose levels, taken during normal working days, are more representative of the usual prevailing levels of circulating glucose than in or outpatient measurements.

Although the level of glycosylated haemoglobin in some way reflects the degree of hyperglycaemia in diabetic patients, the exact relationship between the two is still uncertain. Most studies to date have shown the closest correlations between $\% \mathrm{HbA}_{1}$ and the mean blood glucose levels throughout 24 hours in insulin treated diabetics $[7,10]$. This was also our finding in our group of insulin treated diabetics. As in the study of Gonen et al. [10] we found that neither the peaks of hyperglycaemia nor the amplitude of fluctuation of blood sugar had a disproportionate effect upon blood $\mathrm{HbA}_{1}$ levels.

As regards the period of time over which blood glucose levels affect the $\% \mathrm{HbA}_{1}$, our best correla- tion was with mean blood glucose levels over the previous three months. Others have found correlations with blood glucose at the time of sampling [4], during the previous one to three months [6-10], and during the previous year [12]. One group found a correlation between $\% \mathrm{HbA}_{1}$ separated by electrofocussing and urine testing in the previous eight weeks [9].

Most studies of blood $\mathrm{HbA}_{1}$ levels have involved the separation of the glycosylated haemoglobins by column chromatography. Column methods such as the one used in the present study are rapid and precise although the room temperature and $\mathrm{pH}$ of the eluting buffer are critical. The alternative colorimetric method for total glycosylated $\mathrm{Hb}$ correlated somewhat less well with the mean blood sugar than the column method, but might be preferred for routine use in some laboratories.

Acknowledgements. We are indebted to the staff of the Departments of Chemical Pathology at the Bristol Royal Infirmary and Southmead Hospital for blood glucose determinations, to Mrs Lee Downes and Mrs Gayle Barron for technical assistance, and to Miss Anne Brown for typing the manuscript.

\section{References}

1. Sönksen PH, Judd SL, Lowy C (1978) Home monitoring of blood glucose. Lancet I: 729-732

2. Walford S, Gale EAM, Allison SP, Tattersall RB (1978) Selfmonitoring of blood glucose. Lancet I: 732-735

3. Wakelin K, Goldie DJ, Hartog M, Robinson AP (1978) Measurement of capillary blood glucose in filter-paper spots; an aid to the assessment of diabetic control. Br Med J II: 468-469

4. Trivelli LA, Ranney HM, Hong Tien L (1971) Haemoglobin components in patients with diabetes mellitus. $\mathrm{N}$ Engl J Med 284: $353-357$

5. Fluckiger R, Berger W, Winterhalter KH (1977) Haemoglobin $\mathrm{A}_{1 c}$, a reliable index of diabetic control. Diabetologia 13: 393

6. Welch SG, Boucher BJ (1978) A rapid micro-scale method for the measurement of haemoglobin $\mathrm{A}_{1}(\mathrm{a}+\mathrm{b}+\mathrm{c})$. Diabetologia 14: 209-211

7. Koenig RJ, Peterson CH, Jones RL, Saudek C, Lehrman M, Cerami A (1976) Correlation of glucose regulation and haemoglobin $A_{1 c}$ in diabetes mellitus. $N$ Engl J Med 295: $417-420$ 
8. Graf RJ, Halter JB, Porte D (1978) Glycosylated haemoglobin in normal subjects and subjects with maturity-onset diabetes. Diabetes 27: 834-839

9. Lance R, Soria J, Thibault N, Soria C, Eschwege E, Tchobroutsky G (1977) Glycosylated haemoglobin concentrations and clinitest results in insulin-dependent diabetes. Lancet II: $1156-1157$

10. Gonen B, Rubenstein AH, Rochman H, Tanega SP, Horwitz DL (1977) Haemoglobin $A_{1}$ : An indicator of the metabolic control of diabetic patients. Lancet II: 734-736

11. Bunn HF, Gabbay KH, Gallop PM (1978) The glycosylation of $\mathrm{Hb}$; relevance to diabetes mellitus. Science 200: 21

12. Elkeles RS, Wu J, Hambley J (1978) Haemoglobin $A_{1}$, blood glucose and high density lipoprotein cholesterol in insulinrequiring diabetics. Lancet II: 547-548
13. Hill JB, Palmer PP (1969) Filter paper blood collection and punching as a means of quantification. Clin Chem 15: 381

14. Paisey R, Bradshaw P, Hartog M, West P (1979) Home monitoring of blood glucose using filter paper strips. Br Med J II: 1509

Received: October 9, 1979,

and in revised form: March 7, 1980

Dr. R. B. Paisey

Department of Medicine

Old Building

Bristol Royal Infirmary

Bristol BS2 8HW

England 